\title{
Ascogrammitis lehnertii (Polypodiaceae): a new and dominant understory-species from a diverse community of grammitid ferns in the Andes of Ecuador
}

\author{
Sundue, Michael ; Olivares, Ingrid ; Kessler, Michael
}

\begin{abstract}
In the scope of pantropical studies aimed at understanding how the diversity of grammitid ferns (Polypodiaceae) has evolved and is maintained, we studied a diverse grammitid community in treeline elfin forests in eight study plots of $400 \mathrm{~m} 2$ each at $3200 \mathrm{~m}$ on Cerro Toledo, Loja, southern Ecuador.Werecorded a total of 7986 individuals of 16 grammitid species. Ascogrammitis lehnertii is here described as a newspecies. We also recorded Mycopteris leucosticta, a species previously believed to be restricted to the Choc'o region of Ecuador. We found that the grammitid species were segregated by habitat into trunk-base and trunk specialists, which suggests that species coexistence in these diverse epiphytic communities is at least partly linked to habitat segregation. Ascogrammitis lehnertii and M. leucosticta were the second and third most abundant species, respectively, and both were mostly trunkbase species. The new species A. lehnertii differs from its congeners by the combination of its relatively broad lamina, (2-)3-4 cmwide, fertile leaves bearing $2 \mathrm{mmlong}$ reddish setae in and near the sori, and by bearing proliferous roots from which new plants emerge. Phylogenetic analyses of atpß, rbcL, rps4, trnG-trnR, andtrnL-trnFDNAmolecular sequences, usingmaximum likelihood, place A. lehnertii as sister to A. cuencana with strong support. Despite previous intensive collection efforts in Loja for the past 30 yr, all but one of the collections of this new species were made in the last three years. The discovery of A. lehnertii and the new record of M. leucosticta highlight the patchy distribution of some species in the Andes and the value of surveying.
\end{abstract}

DOI: https://doi.org/10.1600/036364418X697427

Posted at the Zurich Open Repository and Archive, University of Zurich

ZORA URL: https://doi.org/10.5167/uzh-153311

Journal Article

Accepted Version

Originally published at:

Sundue, Michael; Olivares, Ingrid; Kessler, Michael (2018). Ascogrammitis lehnertii (Polypodiaceae): a new and dominant understory-species from a diverse community of grammitid ferns in the Andes of Ecuador. Systematic Botany, 43(3):709-716.

DOI: https://doi.org/10.1600/036364418X697427 
Sundue et al., A New Species of Ascogrammitis 1

SUNDUE ET AL.: A NEW SPECIES OF ASCOGRAMMITIS

Ascogrammitis lehnertii (Polypodiaceae): A New and Dominant Understory-Species from a diverse Community of Grammitid Ferns in the Andes of Ecuador

\section{Michael Sundue, ${ }^{1,3}$ Ingrid Olivares $^{2}$, and Michael Kessler ${ }^{2}$}

${ }^{1}$ The Pringle Herbarium, Department of Plant Biology, University of Vermont, 27 Colchester Avenue, Burlington, Vermont 05405, U. S. A.; sundue@gmail.com

${ }^{2}$ Institute of Systematic and Evolutionary Botany, University of Zurich, Zurich, Switzerland.

${ }^{3}$ Author for correspondence 
Abstract - In the scope of pantropical studies aimed at understanding how the diversity of grammitid ferns (Polypodiaceae) has evolved and is maintained, we studied a diverse grammitid community in treeline elfin forests in eight study plots of $400 \mathrm{~m}^{2}$ each at $3200 \mathrm{~m}$ on Cerro Toledo, Loja, southern Ecuador. We recorded a total of 7986 individuals of 16 grammitid species. Ascogrammitis lehnertii is here described as a new species. We also recorded Mycopteris leucosticta, a species previously believed to be restricted to the Chocó region of Ecuador. We found that the grammitid species were segregated by habitat into trunk-base and trunk specialists, which suggests that species coexistence in these diverse epiphytic communities is at least partly linked to habitat segregation. Ascogrammitis lehnertii and M. leucosticta were the second and third-most abundant species, respectively, and both were mostly trunk-base species. The new species A. lehnertii differs from its congeners by the combination of its relatively broad lamina, (2-)3-4 cm wide, fertile leaves bearing $2 \mathrm{~mm}$ long reddish setae in and near the sori, and by bearing proliferous roots from which new plants emerge. Phylogenetic analyses of atp $\beta, r b c L, r p s 4$, trnG-trnR, and $\operatorname{trn} L$-trnF DNA molecular sequences, using maximum likelihood place A. lehnertii as sister to A. cuencana with strong support. Despite previous intensive collection efforts in Loja for the past 30 years, all but one of the collections of this new species were made in the last three years. The discovery of A. lehnertii and the new record of M. leucosticta highlight the patchy distribution of some species in the Andes and the value of surveying habitats that potentially host unrecognized plant diversity. In order to facilitate further discovery, we provide a key to all species of Ascogrammitis.

Keywords - Amotape-Huncabamba, endemic species, phylogenetics, puna, taxonomy 
The Amotape-Huncabamba Zone in southern Ecuador and northern Peru is a region of high biodiversity and endemism (Borchsenius 1997). The zone acts as a species corridor allowing for interchange between the northern and central Andean species, and the elevational depression of the zone also allows for interchange between the western and eastern cordilleras (Weigend 2002; Quintana et al. 2017). Simultaneously, at the regional level, it is a region with steep and rugged topography, and highly variable geology and climate that results in a landscape of varied and isolated vegetation types (Mandl et al. 2010). The region also has exceptional fern diversity (Kessler and Lehnert 2009a), with many new species being continuously described (e.g., Lehnert and Tejedor 2016; Tejedor and Calatayud 2017). This also applies to the grammitid ferns, a monophyletic lineage of mostly epiphytic ferns belonging to the family Polypodiaceae (Schneider et al. 2004; Ranker et al. 2004; Sundue et al. 2015), which includes some 400 species in the Neotropics and 500 species in the Palaeotropics (Bauret et al. 2017). Previous studies have documented exceptionally rich communities of grammitid ferns in the Amotape-Huncabamba Zone, especially in stunted, mist-shrouded elfin forests on ridges, where up to 20 species of grammitid ferns can be found growing side-by-side (Kessler and Lehnert 2009a, b; Mandl et al. 2010; M. Kessler et al. unpubl. data). How this diversity has evolved and is maintained remains, however, poorly explored. In particular, we know little about habitat segregation among species of grammitid ferns and the potential role of interspecific competition in structuring grammitid communities. Because epiphytic habitats are highly dynamic due to tree growth and damage, it has been argued that epiphytic plant communities experience little competitive pressure (Benzing 2008; Zotz 2016). In order to understand community assembly processes among grammitid ferns, over the last few years we have conducted detailed field surveys in southern Ecuador. We here describe the grammitid community at Cerro Toledo and report the discovery of a new 
species of Ascogrammitis Sundue as well as of a population of Mycopteris leucosticta (J. Sm.) Sundue, a species previously restricted to the Ecuadorian Chocó (Sundue 2014).

\section{MATERIALS AND METHODS}

Study Site - Cerro Toledo is a mountain located in the southwestern corner of Podocarpus National Park in southern Ecuador, which encompasses cloud forests and páramo vegetation at 2300-3300 m elevation. The location and topography of this area produce extreme climatic conditions of high precipitation (up to $6000 \mathrm{~mm}$ per year) and high wind speed (Brunschön and Behling 2009). Despite (or perhaps partly because of) these harsh environmental conditions, of the 52 endemic plant species known from the park, Cerro Toledo was found to harbor the highest percentage of these in sampled plots (Lozano et al. 2010). Thus, there is an endemic flora that seems to benefit from the high rate of species migration and also from the intricate topography of the area that provides numerous microhabitats (Homeier et al. 2008).

Our sampling took place at $3200 \mathrm{~m}$ in the treeline ecotone where vegetation is characterized by patches of dwarf or elfin forest intermixed with tall, shrubby páramo vegetation. Most of the trees are small and form patches of forest with a canopy at 3-4 m height, but a few tall trees (up to $10 \mathrm{~m}$ height) from the cloud forest are still present. Common species belong to the genera Blechnum L. (Blechnaceae), Gaultheria L. (Ericaceae), Loricaria Wedd. (Asteraceae), Meriania Sw. and Miconia Ruiz \& Pav. (Melastomataceae), Myrsine L. (Myrsinaceae), Oreopanax Decn. \& Planch. (Araliaceae), and Podocarpus L'Hér. ex Pers. (Podocarpaceae), among many others (Lozano 2002). 
Grammitid Diversity - In July 2014 we sampled 16 plots of $20 \times 20 \mathrm{~m}^{2}$ at $3200 \mathrm{~m}$ on Cerro Toledo. In each plot, we recorded the abundance of all grammitid species at four different heights (zones) of the trees following the Johansson scheme (Johansson 1974). Because trees at this locality are relatively small, we defined only four instead of the typical five epiphytic zones, namely: zone 1 : base of the trunk at $0-0.50 \mathrm{~m}$, zone 2 : trunk at $0.50 \mathrm{~m}$ to approximately $2 \mathrm{~m}$, zone 3: main branches $2-3 \mathrm{~m}$ and zone 4 : canopy branches at 3-4 $\mathrm{m}$. Within these plots, we estimated the number of mature and juvenile individuals of each species for each zone and collected a voucher and a silica sample for each species; specimens were deposited at the herbaria HUTPL (Loja, Ecuador), VT (USA), and Z/ZH (Switzerland). To test whether different tree zones differ in the assemblage composition and abundance of grammitid species, we performed a principal component analysis (PCA). In order to learn more about Ascogrammitis lehnertii and Mycopteris leucosticta, the focal species of the present paper, we further used contingency tables to specifically test for differences in the number of fertile and sterile individuals between zones in these species.

Molecular Phylogenetic Analyses-The systematic position of A. lehnertii was determined by inclusion of 14 other species of Ascogrammitis for which sequence data was available (Labiak et al. 2010; Sundue et al. 2010; 2014). As outgroups, we included five species of Mycopteris, the sister genus, and one species of Galactodenia, the next closest genus (Sundue et al. 2010, 2014). We PCR-amplified five plastid DNA markers from the holotype: the atp $\beta$ and $r b c L$ coding regions, along with the $r p s 4-\operatorname{trn} S$, $\operatorname{trn} G$-trnR, and the $\operatorname{trn} L-\operatorname{trn} F$ intergenic spacers. DNA extraction and PCR amplification protocols followed those of Labiak et al. (2010). DNA sequencing was performed by Genewiz, Boston, Massachusetts. Sequences generated as part of 
this study were submitted to GenBank. Accession numbers and vouchers for all sequences used in our analyses are provided in Appendix 1. The aligned data matrix is available via Dryad (http://datadryad.org/) under submission \#\#\#\#.

Sequences were edited and contigs were produced using Geneious 6.17 (Biomatters Ltd., San Francisco, California) and the MAFFT plug-in was used to produce alignments (Kato et al. 2013). For each aligned marker, optimal data partitioning and models of substitution evolution were estimated using AICc in PartitionFinder 2 (Lanfear et al. 2012, 2016), which uses PhyML (Guindon et al 2010). The resulting best scheme included three partitions with separate GTR $+\mathrm{G}$ models, atp $\beta$ and $r b c L, r p s 4-t r n S$, and $\operatorname{trn} G$-trnR and $\operatorname{trn} L-\operatorname{trn} F$. These were implemented in likelihood tree searches using RAxML (Stamatakis 2006) through the CIPRES portal (Miller et al., 2010) with independent searches for the 'best tree' and with 1,000 bootstrap replicates.

\section{TAXONOMIC TREATMENT}

Ascogrammitis lehnertii Sundue, sp. nov. TYPE: ECUADOR. Prov. Loja: Podocarpus National Park, Cerro Toledo Area, -4.384526, -79.110965, forest along the road, 3200m, 3 Jul 2014, I. Olivares et al., 158 (holotype: VT!, isotypes: HUTPL!, Z/ZH!).

Differs from all other Ascogrammitis by up to $2 \mathrm{~mm}$ long setae present among the sporangia.

Epiphytes. Roots proliferous and forming new rhizomes. Rhizomes $2-3 \mathrm{~mm}$ wide, rhizome scales $3.5-5 \times 0.5 \mathrm{~mm}$, lanceolate, clathrate, the cell walls dark brown to blackish, the lumina 
clear but narrow, and thus the scales appearing blackish in mass, the margin entire or with occasional marginal cilia, the cilia $0.1 \mathrm{~mm}$ long, dark brown to blackish, the base rounded, subcordate, the apex attenuate, with a minute sub-apical glandular cell. Leaves $10-25 \times(2-) 3-4$ $\mathrm{cm}$, provided with the hyphae and black clavate ascomes of Acrospermum, the ascomes $1 \mathrm{~mm}$ long; petioles 3-6 cm long, blackish, moderately setose, the setae $1-2 \mathrm{~mm}$ long, reddish, spreading; rachis blackish, moderately setose, the setae 1.5-2.0 $\mathrm{mm}$ long, reddish, spreading; laminae narrowly elliptic, widest in the middle, 1-pinnatisect, the base attenuate, with 5-10 pairs of gradually reduced pinnae, the apex acute, pinnatifid; pinnae oblong, medial pinnae $1-2 \times 0.2-$ $0.35 \mathrm{~cm}$, the apices acute, the bases slightly expanded, proximal pinnae gradually reduced to shallow lobes $0.5 \times 3 \mathrm{~mm}$, distal pinnae gradually reduced; pinna costae blackish, visible on both sides of the lamina; veins not darkly colored and not clearly visible; abaxial lamina surface provided with scattered simple 2-celled trichomidia, also moderately setose, the setae 1.5-2.0 $\mathrm{mm}$ long, reddish, spreading, concentrated primarily along the pinna costae and within sori; adaxial lamina surface with occasional $0.2-0.5 \mathrm{~mm}$ long setae along the pinna costae, otherwise glabrous; hydathodes conspicuous, non-cretaceous, or if so then the deposit fallen off of the material seen. Sori medial, slightly elongate. Spores green, normally developed. Figure 1.

Distribution and Ecology — These plants are low-canopy epiphytes forming small colonies from proliferous roots.

The rarity of $A$. lehnertii is difficult to determine. Despite previous intensive collection efforts in Loja for the past 30 years (Kessler and Lehnert 2009a, b; Mandl et al. 2010), all but one of the collections of this new species were made in the last three years. It is common on Cerro Toledo, with over 2000 individuals recorded on $6400 \mathrm{~m}^{2}$, but is known only from two other 
locations. The discovery of this new species highlights the patchy distribution of some species in the Andes and the value of surveying habitats that potentially host unrecognized plant diversity.

Etymology - The new species is named in honor of Marcus Lehnert in recognition of his numerous contributions to fern systematics and taxonomy. Marcus conducted extensive fieldwork near the type locality of the new species, leading to the checklist of Pteridophytes to Reserva Biológica San Francisco, Ecuador (Lehnert et al. 2007).

Notes-Ascogrammitis lehnertii is distinguished from its congeners by the combination of its relatively broad lamina, (2-)3-4 cm wide, fertile leaves bearing $2 \mathrm{~mm}$ long reddish setae in and near the sori, and by bearing proliferous roots from which new plants emerge. Only two other species of Ascogrammitis have proliferous roots, A. anfractuosa (Kunze ex Klotzsch) Sundue and A. alan-smithii (A. Rojas) Sundue. These are easily distinguished by their narrower laminae, (0.4)0.8-1.4 cm wide, and small ovate rhizome scales $0.5-0.7 \times 0.2-0.3 \mathrm{~mm}$ (vs. $3.5-5 \times 0.5 \mathrm{~mm}$ in A. lehnertii). Proliferous roots can be detected on specimens by looking for cases where multiple rhizomes have developed from a single root system. If the proliferous roots are overlooked on specimens, Ascogrammitis lehnertii is likely to be confused with A. loxensis Sundue and A. dilatata Sundue, which share similar laminae, and have non-setose pinna margins. From these, Ascogrammitis lehnertii can be distinguished by the up to $2 \mathrm{~mm}$ long reddish pluricellular setae emerging from the sori. These are in fact the longest abaxial setae of any Ascogrammitis and should distinguish A. lehnertii from all other species in the genus.

Additional Specimens Examined —Ecuador. Prov. LOJA: Podocarpus National Park, Cerro Toledo Area, $-4.384526^{\circ},-79.110965^{\circ}$, forest along the road, 3200m, 3 Jul 2014, I. 
Olivares et al., 142 (HUTPL, VT, Z); idem I. Olivares et al., 143 (HUTPL, VT, Z); idem I. Olivares et al., 160 (VT, Z); Prov. ZAMORA-ChINCHIPE: Podocarpus National Park, Bombuscaro area, forest $5 \mathrm{~m}$ from the walking trail towards "El Mirador", $-4.112886^{\circ}$, 78.968189, 1200 m, 26 Jun 2014, I. Olivares et al., 48 (HUTPL, VT, Z); Road Loma del Oro (S of Saraguro) toward Fierro Urcu, ca. km 9, $3400 \mathrm{~m},\left[-3.95^{\circ},-79.583^{\circ}\right], 12$ Mar 1989, $B$. Øllgaard, J. Madsen and L. Ellemann 91041 (AAU).

\section{RESULTS}

Phylogenetic Analysis - Analysis of cpDNA (Fig. 2) resolved Ascogrammitis as monophyletic with strong bootstrap support (bs 100\%). The overall topology was similar to that of previous studies (Sundue et al, 2010; Sundue et al., 2014), but differed in some respects. In our results, Ascogrammitis nana is resolved as sister to A. anfractuosa in the first divergent clade, whereas in previous analyses it was resolved as sister to A. pichinchense, the second divergent lineage. Similar to previous analyses, the remaining species formed a well-supported clade (bs 100\%), but with some weakly supported internal nodes that inhibit detailed interpretation of the relationships.

Phylogenetic Relations of Ascogrammitis lehnertii - The new species was resolved with strong support (bs 100\%) as sister to A. cuencana (Fig. 2), an infrequently collected species known from the Western cordillera of Ecuador and the Central cordillera of Colombia (Sundue 2010). These species together were supported as sister to A. dilatata, a species known from Bolivia and southern Peru (Sundue and Kessler 2008; Sundue 2011). 
Grammitid Community Assembly - At the type locality on Cerro Toledo, we recorded a total of 7986 individuals of 16 grammitid species in our eight study plots of $400 \mathrm{~m}^{2}$ each. The most abundant species was Stenogrammitis jamesonii (Hook.) Labiak (2472 individuals, 31\%) followed by Ascogrammitis lehnertii (2069 individuals, 26\%), and Mycopteris leucosticta (818 individuals, 10\%). Other five species also had over 100 individuals each. The PCA showed that the vertical distribution of grammitid species was not random (Fig. 3). About $95 \%$ of the variance in the distribution of species was explained by the frequency of species at either the bases of the trees $(\mathrm{z} 1)$ or the trunks $(\mathrm{z} 2)$, and only $5 \%$ of the variance was explained by the frequency of some species on the main branches (z3). Only a few individuals of the two most common species were present on the canopy branches $(\mathrm{z} 4)$, therefore this zone does not explain any of the variance. Differences in the vertical distribution of individuals were significant for the eight most abundant species $\left(\square^{2}=974.61, \mathrm{df}=21, \mathrm{p}<2.2 \mathrm{e}-16\right)$.

The relative distribution of fertile (mature) and sterile (juvenile) individuals also varied within all most common species in the community (Fig. 4). Specifically, for the previously unknown $A$. lehnertii (Fig. 4b) 47\% of all individuals in zone 1 were fertile, whereas in zones $2-4$ only $35 \%$ were fertile $\left(\square^{2}=34.26, \mathrm{df}=3, \mathrm{p}=1.74^{\mathrm{e}-07}\right)$. In Mycopteris leucosticta (Fig. 4c), 52\% of all individuals in zones $1-2$ were fertile, whereas in zone 3 only $36 \%$ were fertile $\left(\square^{2}=9.44\right.$, df $=2$, $\mathrm{p}=0.008)$.

We also recorded three individuals apparently of $A$. lehnertii at Bombuscaro, a locality at lower elevation (1200 m), however, these were sterile and we cannot confirm their identity with certainty.

\section{DISCUSSION}


Ascogrammitis belongs to the Polypodiaceae subfamily Grammitidoideae (PPGI 2016) as evident by the round exindusiate sori, reddish pluricellular setae, and chlorophyllous trilete spores (Sundue et al. 2010). They are predominantly epiphytic species of Neotropical cloud forests, known primarily from the northern and central Andes, with one species ranging into Central America and the West Indies (Sundue 2010). The genus is diagnosed by having dorsiventral rhizomes with ventral root insertion and clathrate rhizome scales with cordate bases and reddish setose margins. The fronds bear numerous reddish setae, and hydathodes are present and often cretaceous (Sundue et al., 2010). The name Ascogrammitis is derived from the relationship of its species with Acrospermum, an epibiotic ascomycete that grows upon the leaves of these ferns. These fungi also occur on the grammitid genus Mycopteris Sundue, and a few other species of Polypodiaceae (Sundue 2010).

With the addition of this new species, Ascogrammitis now comprises 18 species. With the addition of $A$. lehnertii, Ecuador is now home to six species in the genus, the others being $A$. anfractuosa, A. loxensis, A. pichinchae, A. pichinchensis, and A. tungurahuae. With A. lehnertii, A. pichinchensis, and A. tungurahuae being endemic to the country, Ecuador can be said to have the highest number of endemic species of Ascogrammitis compared to other countries.

Grammitid Community Assembly — The grammitid community studied here contained 16 species from eight genera, with an average of 5.8 species per plot of $400 \mathrm{~m}^{2}$. This diversity is equivalent to that found elsewhere in the tropical Andes and Costa Rica at these elevations (Kessler 2001; Kluge et al. 2006; Salazar et al. 2015) as well as in Southeast Asia and New Guinea (Kessler et al. 2001; M. Kessler et al. unpubl. data). The most species-rich genus was Melpomene A. R. Sm. \& R. C. Moran with five species. This genus is typical for high elevation 
forests in the Neotropics and indeed includes the highest-growing vascular epiphytes worldwide (Sylvester et al. 2014). Compared to extensive data of methodologically similar plots elsewhere in the Andes and Central America (e.g., Kessler 2001; Kluge et al. 2006; Salazar et al. 2015), the grammitid community at Cerro Toledo is fairly typical in terms of species richness and abundance of individuals.

Ascogrammitis lehnertii was the second most abundant species at Cerro Toledo after Stenogrammitis jamesonii. These two species showed clear habitat segregation: A. lehnertii was significantly more abundant at the trunk bases whereas $S$. jamesonii, although present from the bases of the trunks to the canopy, showed a clear preference for the branches. Other species of different genera shared these two main microhabitat preferences, with Lellingeria pseudocapillaris (Rosenst.) A.R. Sm. \& R.C. Moran sharing the trunk bases with A. lehnertii, and Moranopteris aphelolepis (C.V. Morton) R.Y. Hirai \& J. Prado preferring higher strata like S. jamesonii. These tendencies were even more pronounced when considering only mature, fertile individuals. In A. lehnertii, for example, these were most abundant at the trunk bases, forming a "source population" whereas mostly sterile individuals were present in the higher zones and conformed "sink populations". Previous studies have shown that microclimatic conditions differ among the epiphyte zones and that they correlate with the distribution of epiphytes (Cardelús and Chazdon 2005; Zotz 2016). Compared to the other zones, the base of the trunk is the most humid and, at this elevation, least cold of all microhabitats (Krömer et al. 2007). Hence, it seems that $A$. lehnertii tends to occupy the less extreme part of the microenvironmental gradient in the forest patches of Cerro Toledo, although light is presumably most limited here. Clearly, different species of grammitid ferns show different microhabitat preferences, but to which degree these are driven by the ecophysiologically determined 
adaptations of the species or by competitive interactions between species (Karger et al. 2015) remains to be studied in detail. In any case, species coexistence in these diverse epiphytic communities is linked to habitat segregation.

The new record of Mycopteris leucosticta, a species previously restricted to the Chocó of Ecuador confirms that migration of the species occurs across the Amotape-Huancabamba zone. Several studies have demonstrated the important role of this area, which constitutes a corridor for the dispersal of mountain and lowland species in both directions North-South and West-East (Weigend 2002).

\section{KEY TO THE SPECIES OF ASCOGRAMMITIS}

Note: A. dilatata and A. loxensis are keyed twice to accommodate variation.

1. Roots proliferous, plants forming small to large colonies.

2. Rhizome scales lanceolate, $3.5-5 \mathrm{~mm}$ long; leaves $10-25 \times(2-) 3-4 \mathrm{~cm}$ A. lehnertii

2. Rhizome scales ovate, $0.5 \mathrm{~mm}$ long; leaves $5-10 \times 0.9-1.4 \mathrm{~cm}$

3. Hydathodes cretaceous; segment margins setose; adaxial lamina surface with scattered setae; rhizome scale margin entire; plants apparently lacking the mycelia and ascomes of Acrospermum; epiphytic, 750-1200 m (Mesoamerica).......A. alan-smithii

3. Hydathodes cretaceous or not; segment margins setose or not; adaxial lamina surface glabrous or with scattered setae; rhizome scale margins entire or ciliate; plants with mycelia and ascomes of Acrospermum; epiphytic or epipetric, 1000$3000 \mathrm{~m}$ (widespread) A. anfractuosa

1. Roots not proliferous, plants individual.

4. Segments deeply and regularly pinnatifid (Peru, Bolivia). A. athyrioides 
4. Segments entire or minutely denticulate, but not distinct (central and northern Andes).

5. Segment margins and apices evenly setose.

6. Laminae membranaceous; fronds pendent; segment apices rounded; dark sclerenchyma of segment costae usually not visible abaxially (Ecuador).

A. pichinchensis

6. Laminae chartaceous; fronds erect, arching, or pendent; segment apices acute; dark sclerenchyma of segment costae visible abaxially (central and northern Andes).

7. Petiole setae 1-2.5 mm long; setae of segment margins $0.5-1 \mathrm{~mm}$ long; sori distributed evenly throughout the frond; segment bases neither conspicuously decurrent or surcurrent (Colombia, Ecuador)........................................... pichinchae

7. Petiole setae $0.5-1.5 \mathrm{~mm}$ long; setae of segment margins $0.5 \mathrm{~mm}$ long; sori confined to the distal portions of the lamina; segment bases decurrent and sucurrent, the proximal ones often conspicuously dilated.

8. Lamina base short attenuate, with 4-8 pairs of reduced segments; rhizome scales $1.5-3 \times 0.2-0.3 \mathrm{~mm}$; petioles sparsely setose; segment margins irregularly setose; lamina green (central Peru, Bolivia) A. dilatata

8. Lamina base long attenuate, with 16-20 pairs of reduced segments; rhizome scales $2.3-4.2 \times 0.3-0.6 \mathrm{~mm}$; petioles moderately setose; segment margins regularly setose; lamina bluish-green (Ecuador, N Peru). A. loxensis 
5. Segment margins glabrous or provided with minute hairs, but not setose, segment apices glabrous or provided with 1-3 setae in A. colombiensis, A. cuencana, $A$. david-smithii, A. nana, A. stuebelii.

9. Petiole setae $0.2-0.4 \mathrm{~mm}$ long; surface of rhizome scales ciliate or glabrous.

10. Rhizome scales ciliate on surfaces as well as margins; fronds; $19-38 \times 2-$ 4.6(-6), (N Peru). A. oxapampensis

10. Rhizome scales glabrous on surfaces, ciliate on margins; fronds $8-13 \times 1.4-$ $2 \mathrm{~cm}$ (Colombia) A. stuebelii

9. Petiole setae 1-2.5 mm long; surface of rhizome scales glabrous, the margin ciliate.

11. Laminae 5-7.5 cm wide; 14-22 sori per segment; rhizome scales $4.5 \mathrm{~mm}$ long; abaxial lamina surface moderately to densely and evenly provided with erect setae, the sterile and fertile portions of the abaxial lamina equally setose (Bolivia) A. clathrata

11. Laminae up to $4.5 \mathrm{~cm}$ wide; $3-14$ sori per segment; rhizome scales 3-3.5 mm long; abaxial lamina nearly glabrous to densely setose, the fertile portions of the abaxial lamina generally more densely setose than sterile portions.

12. Hydathodes non-cretaceous; rhizomes bearing branch buds; petiole bases with two vascular bundles (check the portion of the petiole immediately adjacent to the rhizome).

13. Abaxial lamina moderately setose, the setae $0.5-1 \mathrm{~mm}$ long; rhizome scales 2.5-3.5 mm long (Colombia) A. colombiensis 
13. Abaxial lamina glabrous or with scattered setae $0.5 \mathrm{~mm}$ long; rhizome scales 4-5 mm long (Venezuela). A. clavigera

12. Hydathodes cretaceous (the whitish deposit sometimes lost); rhizomes lacking branch buds; petioles with a single vascular bundle (check the portion of the petiole immediately adjacent to the rhizome).

14. Fronds $14-20 \times 0.8-2.8 \mathrm{~cm}$, erect.

15. Rhizome scales $0.2-0.3 \mathrm{~mm}$ wide; petiole setae $1.5-2 \mathrm{~mm}$ long; laminae 1.2-2.8 cm wide (Peru, Bolivia). A. nana

15. Rhizome scales $0.7 \mathrm{~mm}$ wide; petiole setae $0.5-1 \mathrm{~mm}$ long; laminae 0.8-1.6 cm wide (Colombia, Ecuador) A. cuencana

14. Fronds $18-60 \times 2-4.5 \mathrm{~cm}$, arching or pendant.

16. Laminae deeply 1-pinnatifid to 1-pinnatisect, the tissue between segments sometimes very narrow, but always connected.

17. Receptacular setae absent; sori 4-8 per segment, evenly distributed throughout the lamina; pinna costae not readily visible abaxially (Colombia) A. angustipes

17. Receptacular setae present; sori up to 12 per segment, usually confined to the distal portion of the lamina; pinna costae visible abaxially

18. Lamina base short attenuate, with 4-8 pairs of reduced segments; rhizome scales $1.5-3 \times 0.2-0.3 \mathrm{~mm}$; petioles sparsely setose; segment margins irregularly setose; lamina green (central Peru, Bolivia) A. dilatata 
18. Lamina base long attenuate, with 16-20 pairs of reduced segments; rhizome scales $2.3-4.2 \times 0.3-0.6 \mathrm{~mm}$; petioles moderately setose; segment margins regularly setose; lamina bluish-green (Ecuador, N Peru). A. loxensis

16. Laminae 1-pinnate nearly throughout.

19. Rhizome scales with narrow indistinct lumina, blackish in mass; fronds 27-60 cm long (Ecuador) A. tungurahuae 19. Rhizome scales with broad distinct lumina, dark grey in mass; fronds 18-37 cm long (Bolivia)

A. david-smithii

\section{ACKNOWLEDGMENTS}

We thank Oriane Loiseau for participating in the field work on Cerro Toledo, and the Ecuadorean authorities for granting research permits. Thanks to Susan Fawcett for preparing the illustration. This study was funded by a grant of the Swiss National Science Foundation (CRSII3_147630).

\section{AUTHOR CONTRIBUTIONS}

The morphological diagnosis and phylogenetic analyses were conducted by MS. Field work and the analysis of community assembly were conducted by IO. All three authors conceived and contributed to writing the manuscript.

\section{LITERATURE CITED}

Bauret, L., M. Gaudeul, M. A. Sundue, B. S. Parris, T. A. Ranker, F. Rakotondrainibe, S. Hennequin, J. Ranaivo, M. A. Selosse and G. Rouhan,. 2017. Madagascar sheds new light 
on the molecular systematics and biogeography of grammitid ferns: New unexpected lineages and numerous long-distance dispersal events. Molecular Phylogenetics and Evolution 111:1-17.

Benzing, D. H. 2008. Vascular epiphytes: general biology and related biota. Cambridge University Press.

Borchsenius, F. 1997. Patterns of plant species endemism in Ecuador. Biodiversity and Conservation 6: 379-399.

Brunschön, C. and H. Behling. 2009. Late Quaternary vegetation, fire and climate history reconstructed from two cores at Cerro Toledo, Podocarpus National Park, southeastern Ecuadorian Andes. Quaternary Research 72: 388-399.

Cardelús, C. L. and R. L. Chazdon. 2005. Inner-crown microenvironments of two emergent tree species in a lowland wet forest. Biotropica 37: 238-244.

Guindon, S., J. F. Dufayard, V. Lefort, M. Anisimova, W. Hordijk, and O. Gascuel. 2010. New algorithms and methods to estimate maximum-likelihood phylogenies: assessing the performance of PhyML 3.0. Systematic Biology 59: 307-321.

Homeier, J., F. A. Werner, S. R. Gradstein, S. Breckle, and M. Richter. 2008. Potential vegetation and floristic composition of Andean forests in South Ecuador, with a focus on the RBSF. Ecological Studies 198: 87

Johansson, D. 1974. Ecology of vascular epiphytes in West African rain forest. Acta Phytogeogrica Suecica 59:1-136.

Karger, D. N., H. Tuomisto, V. B. Amoroso, D. Darnaedi, A. Hidayat, S. Abrahamczyk, J. Kluge, M. Lehnert, and M. Kessler. 2015. The importance of species pool size for community composition. Ecography 38: 1243-1253. 
Katoh, K. and Standley, D. M., 2013. MAFFT multiple sequence alignment software version 7: Improvements in performance and usability. Molecular biology and evolution 30: 772-780.

Kessler, M. 2001. Pteridophyte species richness in Andean forests in Bolivia. Biodiversity and Conservation 10: 1473-1495.

Kessler, M. and M. Lehnert. 2009a. Do ridge habitats contribute to pteridophyte diversity in tropical montane forests? A case study from southeastern Ecuador. Journal of Plant Research 122: $421-428$.

Kessler, M. and M. Lehnert. 2009b. Are ridge habitats special sites for endemic plants in tropical montane rain forests? A case study of pteridophytes in Ecuador. Folia Geobotanica 44: $387-398$.

Kessler, M., B. S. Parris, and E. Kessler. 2001. A comparison of the tropical montane pteridophyte communities of Mount Kinabalu, Borneo, and Parque Nacional Carrasco, Bolivia. Journal of Biogeography 28: 611-622.

Kluge, J., M. Kessler and R. Dunn. 2006. What drives elevational patterns of diversity? A test of geometric constraints, climate, and species pool effects for pteridophytes on an elevational gradient in Costa Rica. Global Ecology and Biogeography 15: 358-371

Krömer, T., M. Kessler, and S. R. Gradstein. 2007. Vertical stratification of vascular epiphytes in submontane and montane forest of the Bolivian Andes: The importance of the understory. Plant Ecology 189: 261-278.

Labiak, P. H., M. Sundue, and G. Rouhan. 2010. Molecular phylogeny, character evolution, and biogeography of the grammitid fern genus Lellingeria (Polypodiaceae). American Journal of Botany 97: 1354-1364. 
Lanfear, R., B. Calcott, S. Y. Ho, and S. Guindon. 2012. PartitionFinder: Combined selection of partitioning schemes and substitution models for phylogenetic analyses. Molecular Biology and Evolution 29: 1695-1701.

Lanfear, R., P. B. Frandsen, A. M. Wright, T. Senfeld, and B. Calcott. 2016. PartitionFinder 2: New methods for selecting partitioned models of evolution for molecular and morphological phylogenetic analyses. Molecular Biology and Evolution 34: 772-773.

Lehnert, M. and A. Tejedor. 2016. Three new scaly tree fern species (Cyathea-Cyatheaceae) from the Amotape-Huancabamba Zone and their biogeographic context. American Fern Journal 106: $175-190$.

Lehnert M., M. Kessler, L. I. Salazar, H. Navarrete, F. A. Werner, and S. R. Gradstein. 2007. Pteridophytes: Preliminary checklists of Reserva Biológica San Francisco, Ecuador. Ecotropical Monographs 4: 59-68

Lozano, P. 2002. Los tipos de bosque en el sur de Ecuador. Pp. 29-50 in Botánica Austroecuatoriana - Estudios sobre los recursos vegetales en las provincias de El Oro, Loja y Zamora-Chinchipe. Eds. Z. Aguirre M., J. E. Madsen, E. Cotton and H. Balslev. Quito: Ediciones Abya Yala,

Lozano, P., M. Kuepper, and R. Bussmann. 2010. Plant diversity of páramo and Andean elfin forest in Podocarpus National Park - Loja, Ecuador. Arnaldoa 17:193-202.

Mandl, N., M. Lehnert, M. Kessler, and S. R. Gradstein. 2010. A comparison of alpha and beta diversity patterns of ferns, bryophytes and macrolichens in tropical montane forests of southern Ecuador. Biodiversity and Conservation 19:2359-2369. 
Miller, M. A., W. Pfeiffer, and T. Schwartz. 2010. Creating the CIPRES Science Gateway for inference of large phylogenetic trees. Pp. 1-8 in Gateway Computing Environments Workshop (GCE). New Orleans: Gateway Computing.

PPG I. 2016. A community-derived classification for extant lycopods and ferns. Journal of Systematics and Evolution 54: 563-603.

Quintana, C., R. T. Pennington, C. U. Ulloa and H. Balslev. 2017. Biogeographic barriers in the Andes: Is the Amotape-Huancabamba Zone a dispersal barrier for dry forest plants? Annals of the Missouri Botanical Garden 102: 542-550.

Rambaut, A., M. A. Suchard, D. Xie, and A. J. Drummond. 2013. Tracer v 1.5. Available from http://beast.bio.ed.ac.uk/Tracer.

Ranker, T.A., A. R. Smith, B. S. Parris, J. M. Geiger, C. H. Haufler, S. C. Straub, and H. Schneider. 2004. Phylogeny and evolution of grammitid ferns (Grammitidaceae): A case of rampant morphological homoplasy. Taxon 53: 415-415.

Salazar, L., J. Homeier, M. Kessler, S. Abrahamczyk, M. Lehnert, T. Krömer and J. Kluge. 2015. Diversity patterns of ferns along elevational gradients in Andean tropical forests. Plant Ecology and Diversity 8: 13-24.

Schneider, H., A. R. Smith, R. Cranfill, T. J. Hildebrand, C. H. Haufler and T. A. Ranker. 2004. Unraveling the phylogeny of polygrammoid ferns (Polypodiaceae and Grammitidaceae): Exploring aspects of the diversification of epiphytic plants. Molecular Phylogenetics and Evolution 31: 1041-1063.

Stamatakis, A. 2006. RAxML-VI-HPC: Maximum likelihood-based phylogenetic analyses with thousands of taxa and mixed models. Bioinformatics 22: 2688-2690. 
Sundue, M. A. 2010. A monograph of Ascogrammitis, a new genus of grammitid ferns (Polypodiaceae). Brittonia 62: 357-399.

Sundue, M. A. 2011. Helechos y lycophytas. Flora de la Región del Parque Nacional Amboró. Santa Cruz de la Sierra, Bolivia: Editorial FAN.

Sundue, M. A. 2014. Mycopteris, a new neotropical genus of grammitid ferns (Polypodiaceae). Brittonia 66:174-185.

Sundue, M. and M. Kessler. 2008. New species and new records of the fern genus Terpsichore (Polypodiopsida: Polypodiaceae) from Bolivia. Organisms Diversity \& Evolution 8: 163-e1. Sundue, M. A., M. B. Islam, and T. A. Ranker. 2010. Systematics of grammitid ferns (Polypodiaceae): Using morphology and plastid sequence data to resolve the circumscription of Melpomene and the polyphyletic genera Lellingeria and Terpsichore. Systematic Botany 35: 701-715.

Sundue, M. A., B. S. Parris, T. A. Ranker, A. R. Smith, E. L. Fujimoto, D. Zamora-Crosby, C. W. Morden, W.-L. Chiou, C. W. Chen, R. Rouhan, R. Y. Hirai, and J. Prado. 2014. Global phylogeny and biogeography of grammitid ferns (Polypodiaceae). Molecular Phylogenetics and Evolution 81: 195-206.

Sundue, M.A., W. L. Testo and T. A. Ranker. 2015. Morphological innovation, ecological opportunity, and the radiation of a major vascular epiphyte lineage. Evolution 69: 24822495.

Sylvester, S.P., M. D.P.V. Sylvester, and M. Kessler. 2014. The world's highest epiphytes found in the Peruvian Andes. Alpine Botany 124: 179-185.

Tejedor, A. and G. Calatayud. 2017. Eleven new scaly tree ferns (Cyathea: Cyatheaceae) from Peru. American Fern Journal 107: 156-191. 
Weigend, M. 2002. Observations on the biogeography of the Amotape-Huancabamba zone in northern Peru. The Botanical Review 68: 38-54.

Zotz, G. 2016. Epiphyte Communities. Pp. 167-202 in Plants on Plants - The Biology of Vascular Epiphytes, Ed. G. Zotz. Berlin. Springer International Publishing. 
FIG. 1. Ascogrammitis lehnertii A. Habit, scale bar $=1 \mathrm{~cm}, \mathrm{~B}$. Detail adaxial lamina (Olivares et al., 142, VT).

FIG. 2. Best tree resulting from the maximum likelihood analysis of the five chloroplast markers (atpB, rbcL, rps4, trnL-trnF, trnG-trnR). Numbers at nodes are bootstrap support values. Scale bar represents substitutions per site.

FIG. 3. Principal component analysis (PCA) for the relative abundance of species present in four Johansson epiphytic-zones (z1-z4) at Cerro Toledo. Species were distributed in four groups, one group (black dotted ellipse) preferred the bases of the trees (Johansson zone 1, z1), a second group (solid black ellipse) contained species that were only present on the trunk (z2), the third group did not show a clear preference between the trunks and main branches (z1-z3, grey solid ellipse), and group four included species with relative high abundances on the main branches (z3, dashed-dotted ellipse). The size of species names indicates the relative abundance of each species. Full species names: Alansmia laxa, A. stella var. flava, A. stella var. stella, Ascogrammitis lehnertii, Grammitis bryophila, Lellingeria pseudocapillaris, Melpomene erecta, M. flabelliformis, M. pseudonutans, M. sodiroi, M. cf. personata, Moranopteris aphelolepis, M. longisetosa, Mycopteris leucosticta, M. subtilis, Stenogrammitis jamesonii.

FIG. 4. Vertical distribution of the eight most abundant grammitid species on Cerro Toledo following the vertical zonation of Johansson with zone 1 corresponding to the trunk bases, zone 2 to the trunks, zone 3 to the main branches, and zone 4 to the canopy branches. Bars indicate the number of sterile (gray) and fertile (black) individuals per zone. In the two rightmost panels we 
show the total numbers of individuals (i) and species (j) per zone. (a) Stenogrammitis jamesonii, (b) Ascogrammitis lehnertii, (c) Mycopteris leucosticta, (d) Lellingeria pseudocapillaris, (e) Melpomene sodiroi, (f) Moranopteris aphelolepis, (g) Melpomene cf. personata, (h) Alansmia laxa. 


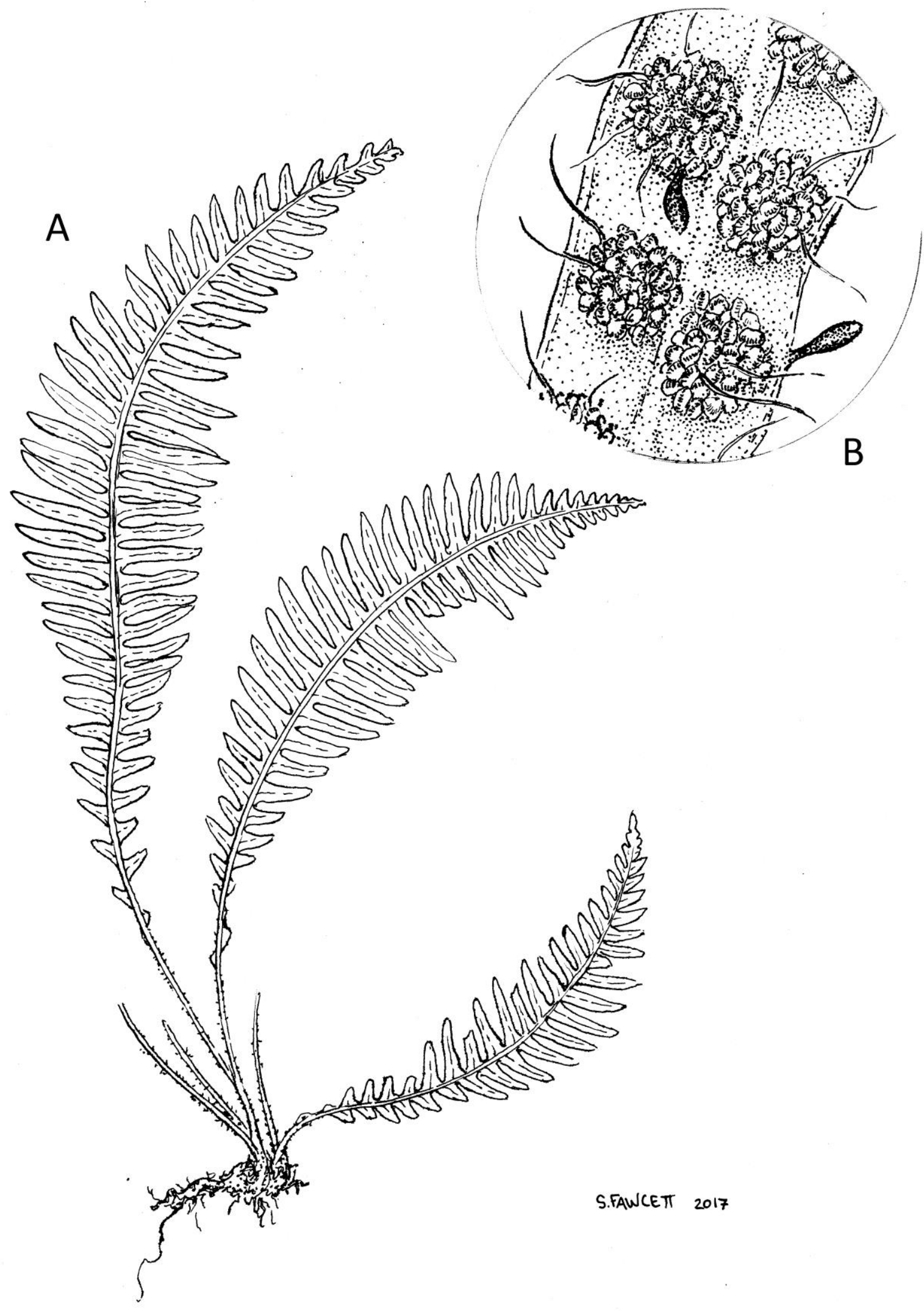


Sundue et al., A New Species of Ascogrammitis 27

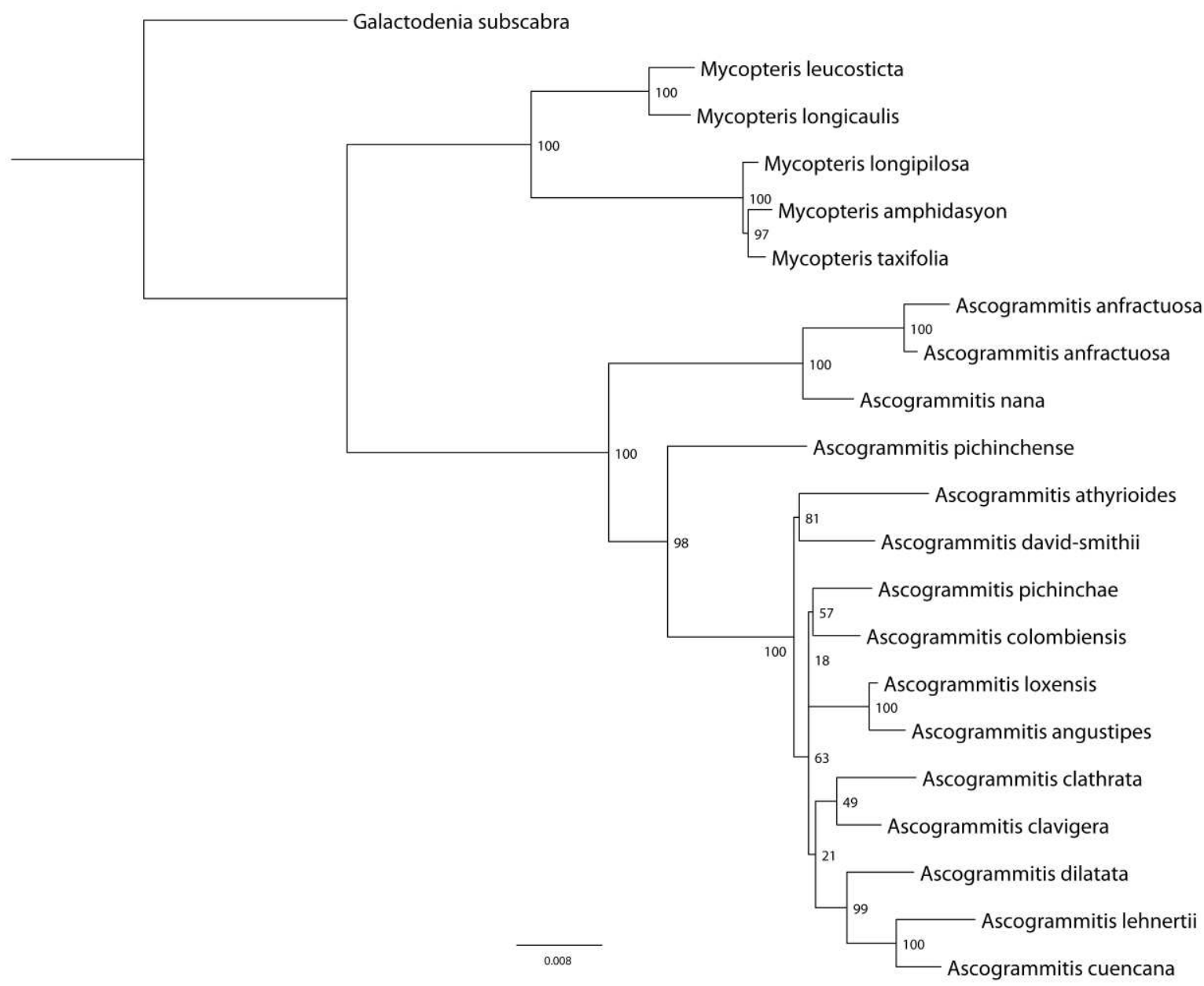


Sundue et al., A New Species of Ascogrammitis 28

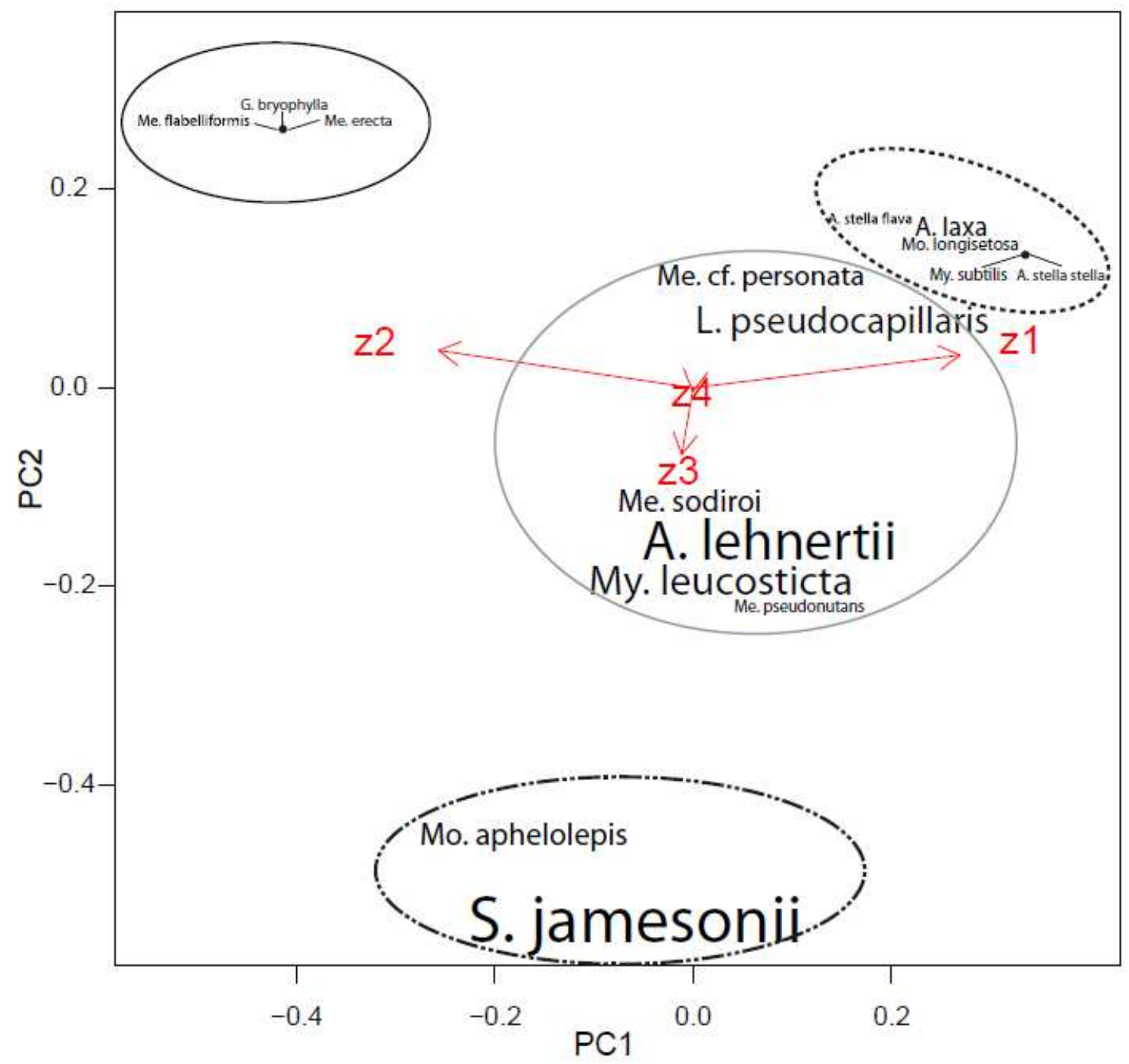


Sundue et al., A New Species of Ascogrammitis 29

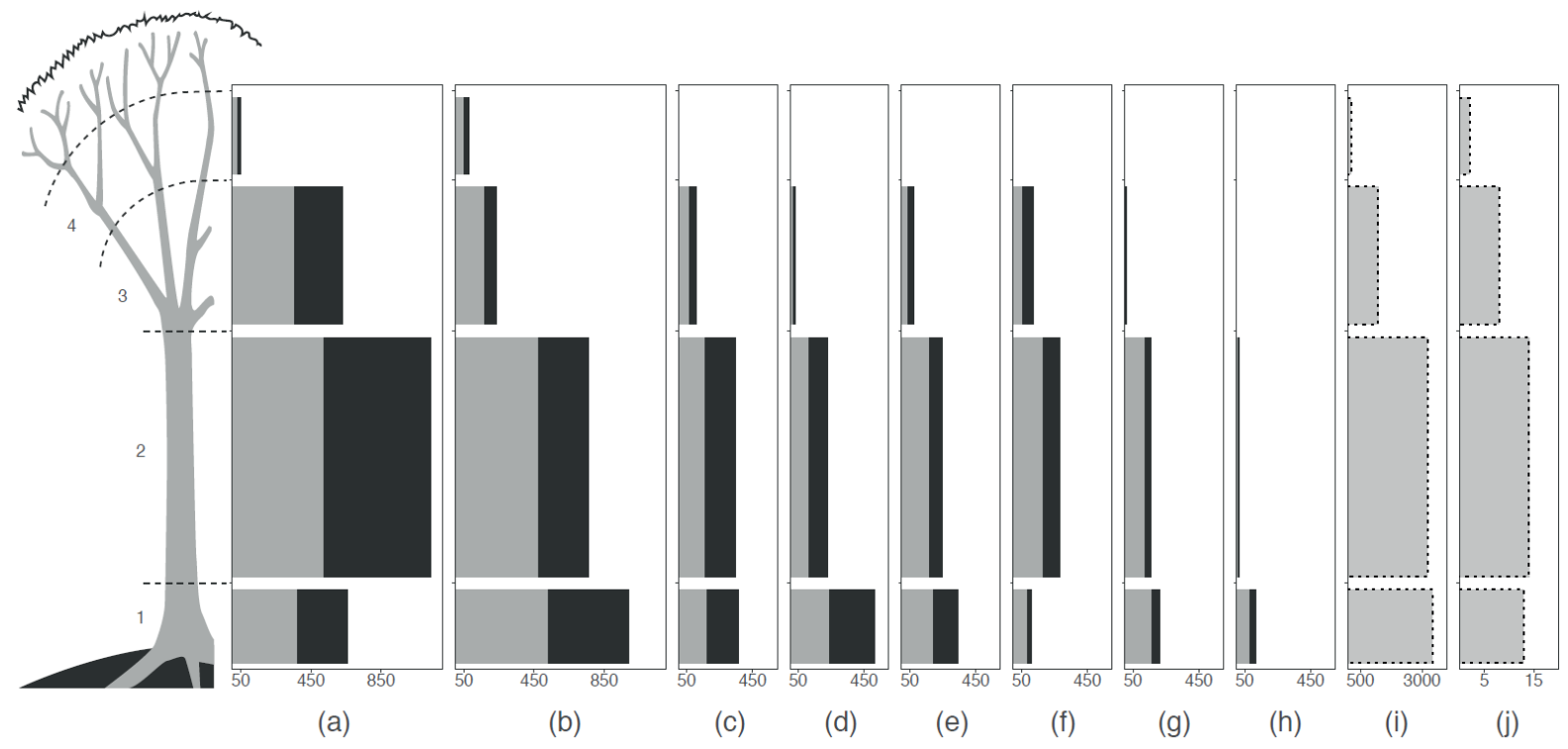


2 Appendix 1. Table of GenBank accession numbers. Accession numbers in boldface refer to sequences generated as part of this study.

\begin{tabular}{|c|c|c|c|c|c|c|c|}
\hline Taxon & Voucher & Country & atp B & rbcL & rps4-trnS & $\operatorname{trn} G-\operatorname{trn} R$ & trnL-trnF \\
\hline \multicolumn{8}{|l|}{ Ascogrammitis } \\
\hline anfractuosa & Lehnert 1035, NY & Ecuador & GU476783 & GU476853 & KM106108 & KM105967 & GU476675 \\
\hline \multicolumn{8}{|l|}{ Ascogrammitis } \\
\hline anfractuosa & Kessler 14867, VT & Colombia & MG948936 & MG948938 & MG966515 & MG966517 & MG966519 \\
\hline Ascogrammitis angustipes & Sundue 1237, NY & Colombia & KM218837 & GU476891 & KM106109 & KM105968 & GU476703 \\
\hline Ascogrammitis athyrioides & Lehnert 261, NY & Bolivia & KM218840 & GU476856 & KM106110 & KM105969 & GU476704 \\
\hline Ascogrammitis clathrata & Kromer 1237, NY & Bolivia & KM218838 & GU476843 & KM106111 & KM105970 & GU476708 \\
\hline Ascogrammitis clavigera & Schneider 2400 & Venezuela & KM218839 & GU476925 & KM106112 & KM105971 & GU476709 \\
\hline Ascogrammitis & Sundue \& Vasco 1316, & & & & & & \\
\hline colombiensis & NY & Colombia & GU476804 & GU476900 & KM106113 & N/A & GU476710 \\
\hline Ascogrammitis cuencana & Lehnert 1164, NY & Ecuador & $\mathrm{N} / \mathrm{A}$ & GU476851 & KM106114 & GU387205 & GU476714 \\
\hline \multicolumn{8}{|l|}{ Ascogrammitis david- } \\
\hline smithii & Sundue $785, N Y$ & Bolivia & GU476794 & GU387012 & GU387122 & $\mathrm{N} / \mathrm{A}$ & GU476688 \\
\hline Ascogrammitis dilatata & Labiak 4728, NY & Bolivia & GU376640 & GU387033 & GU387124 & GU387206 & GU387285 \\
\hline Ascogrammitis lehnertii & Olivares 142, VT & Ecuador & MG948937 & MG948939 & MG966516 & MG966518 & MG966520 \\
\hline Ascogrammitis loxensis & Sundue $1164, \mathrm{NY}$ & Ecuador & GU476812 & GU386995 & GU387125 & GU387207 & GU476721 \\
\hline Ascogrammitis nana & Labiak 4725, NY & Bolivia & GU376642 & GU387031 & GU387126 & GU387208 & GU387287 \\
\hline Ascogrammitis pichinchae & Wilson 2816a, NY & Ecuador & AY459508 & GU476928 & KM106115 & N/A & GU476730 \\
\hline $\begin{array}{l}\text { Ascogrammitis } \\
\text { pichinchense }\end{array}$ & Lehnert 1577, NY & Ecuador & GU476816 & GU476854 & KM106116 & N/A & GU476732 \\
\hline Galactodenia subscabra & Moran 8078, NY & Ecuador & GU476821 & GU476860 & GU387127 & GU387209 & GU476739 \\
\hline Mycopteris amphidasyon & Moran 7646, NY & Ecuador & GU476759 & GU476922 & KM106161 & KM106007 & GU476638 \\
\hline Mycopteris leucosticta & Lehnert 1128, NY & Ecuador & GU476811 & GU476848 & KM106162 & $\mathrm{N} / \mathrm{A}$ & GU476720 \\
\hline Mycopteris longicaulis & Jimenez 373, NY & Bolivia & GU476813 & GU476840 & KM106163 & $\mathrm{N} / \mathrm{A}$ & GU476724 \\
\hline & Sundue \& Martin 1033, & & & & & & \\
\hline Mycopteris longipilosa & NY & Ecuador & GU476814 & GU476861 & KM106164 & KM106008 & GU476726 \\
\hline Mycopteris taxifolia & Labiak 4018, NY & Brazil & GU476800 & GU476914 & KM106167 & KM106009 & GU476699 \\
\hline
\end{tabular}


Sundue et al., A New Species of Ascogrammitis 31 


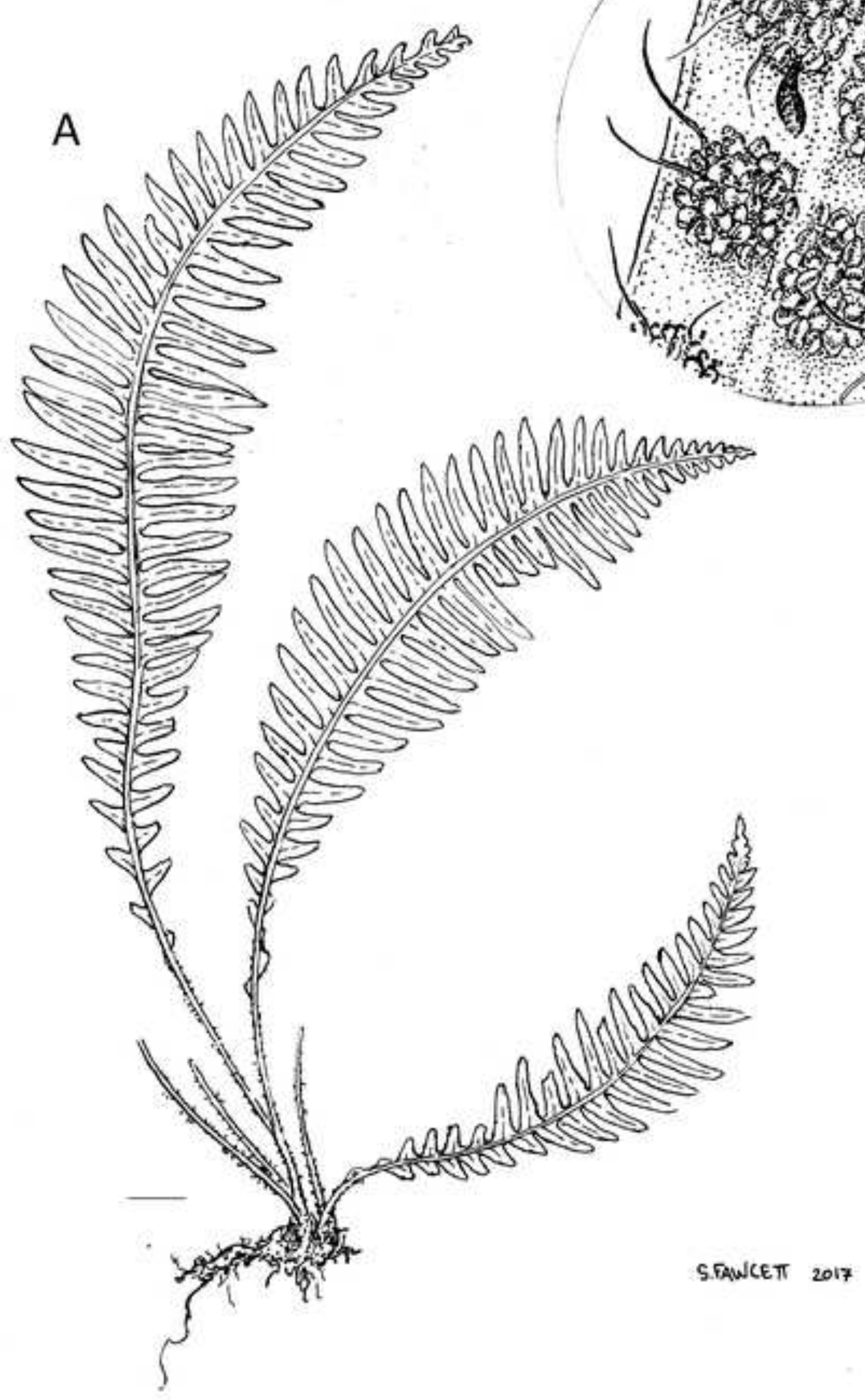




\section{Galactodenia subscabra}

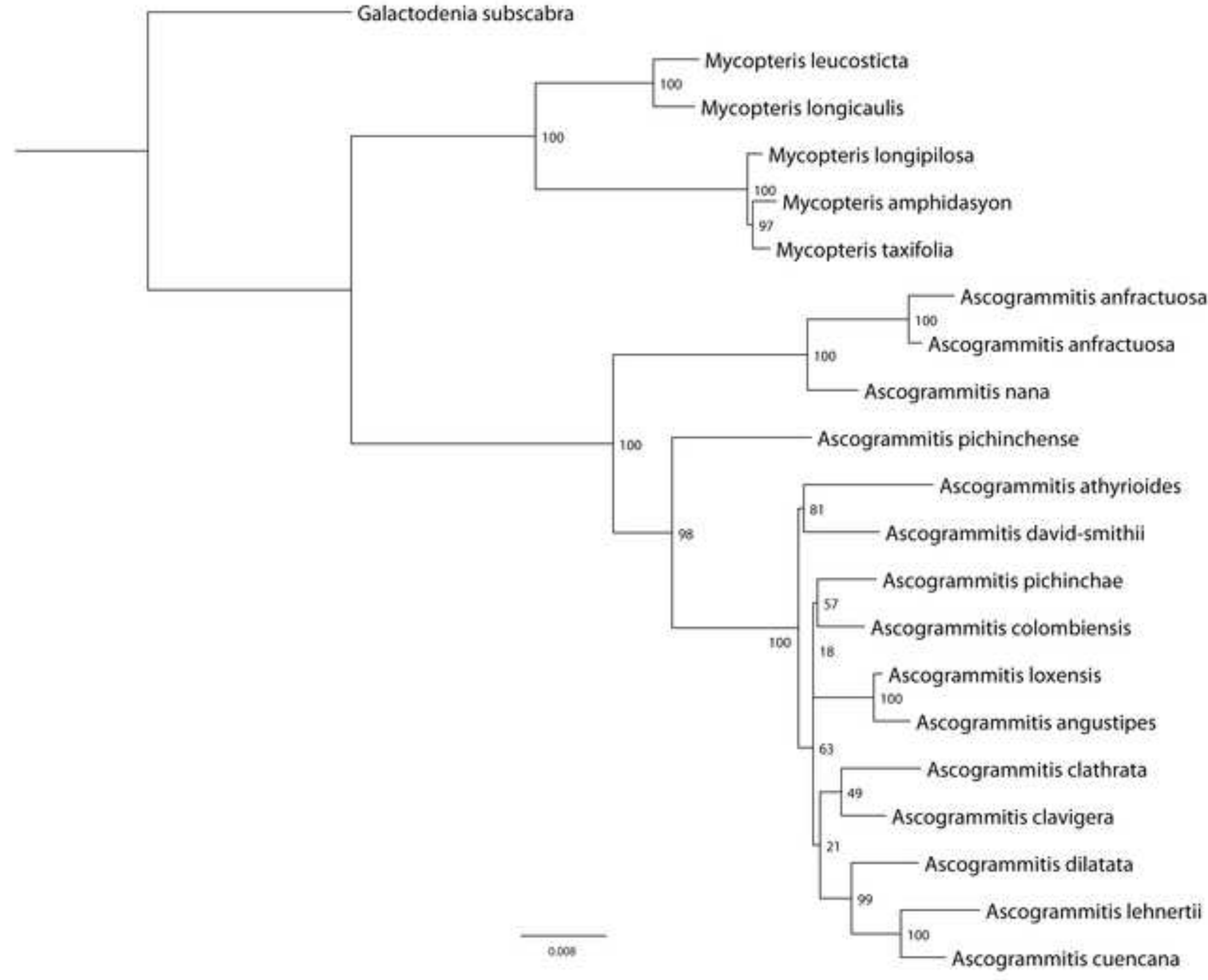




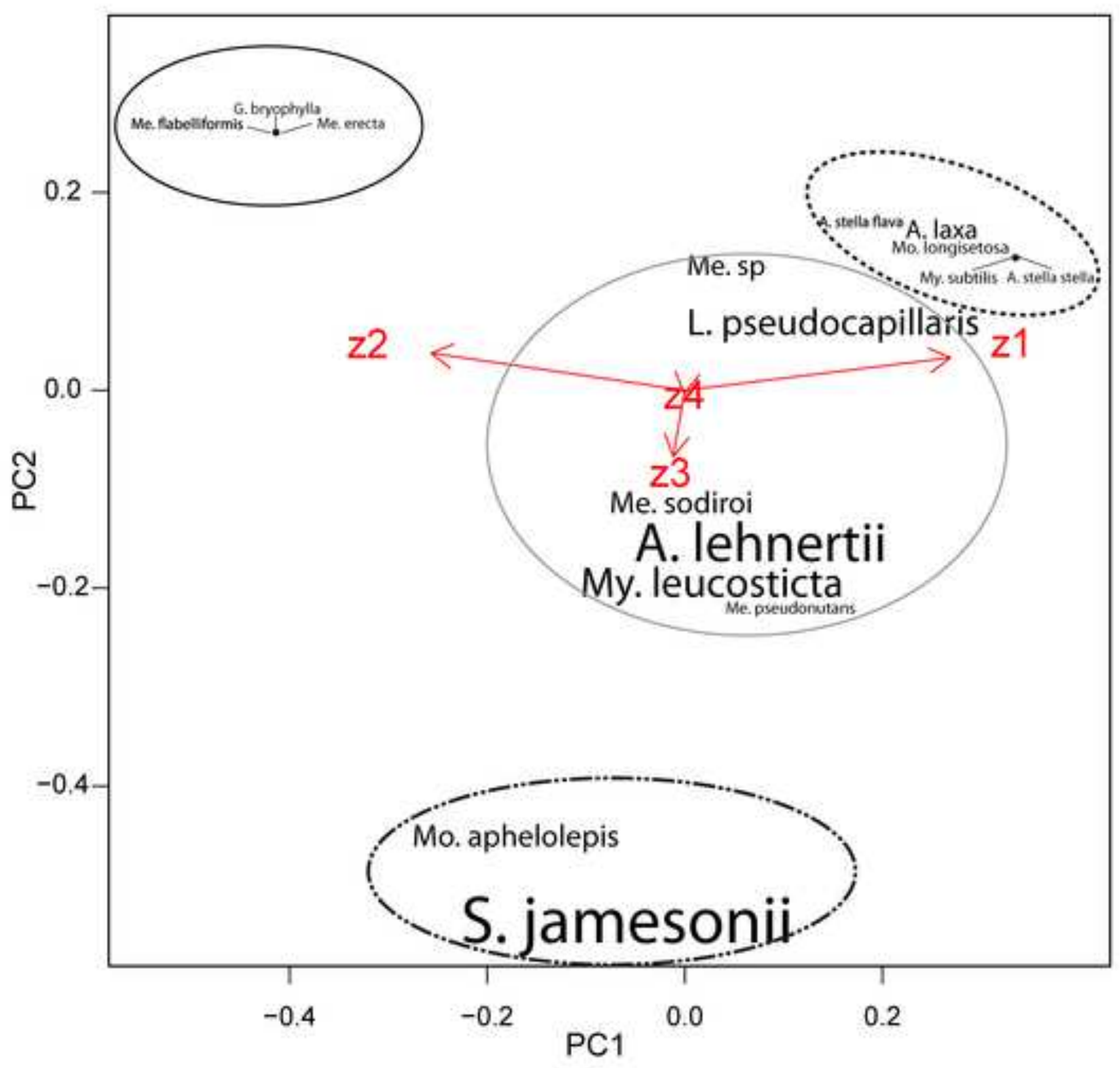




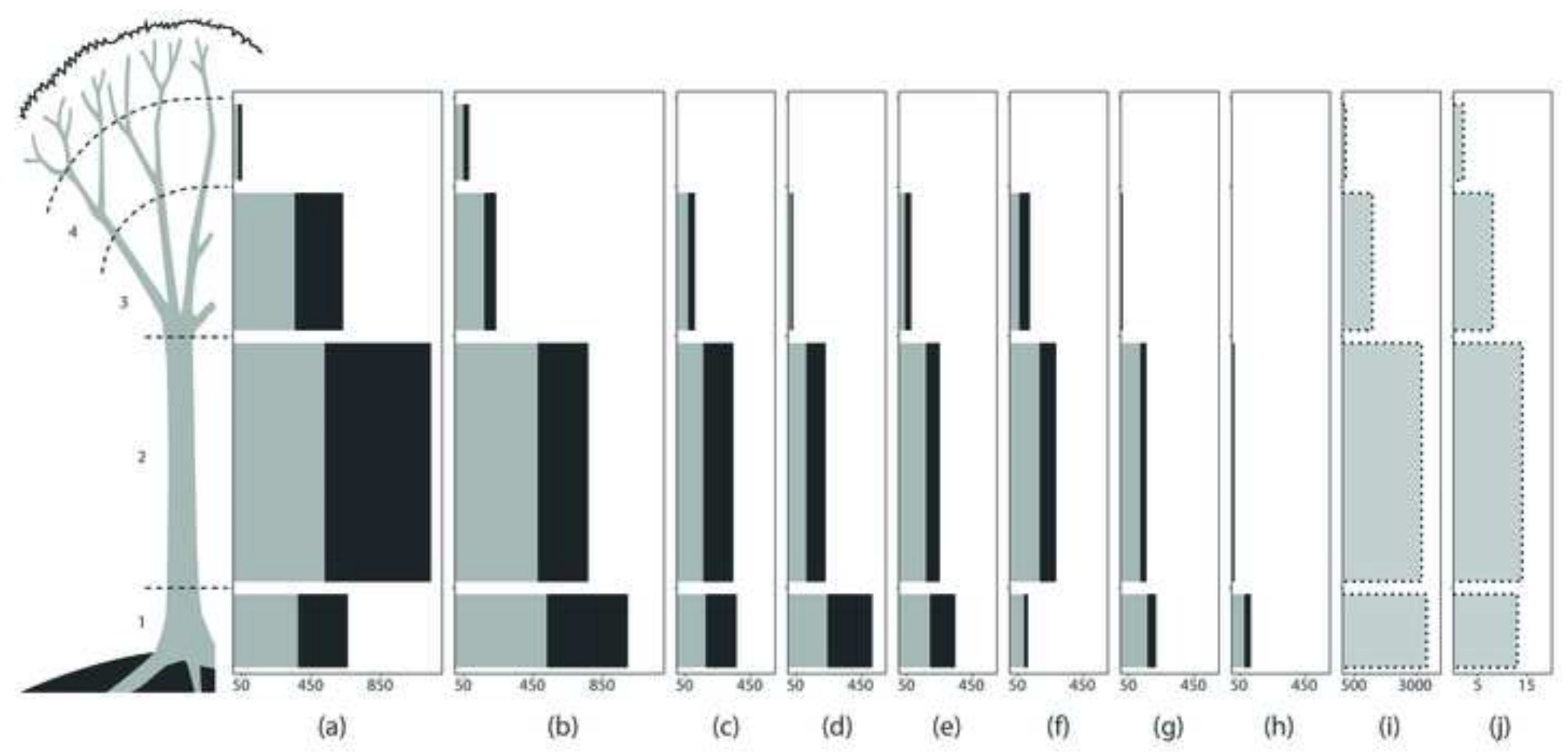

